\title{
The Use of Black English in American Literature: The Case of Mark Twain's Huckleberry Finn
}

\author{
Yamina ILES \\ Department of English \\ FLPATP Research Laboratory $N^{\circ} 72$ \\ Faculty of Letters and Languages \\ University of Tlemcen, Tlemcen, Algeria \\ Amine BELMEKKI \\ Department of English \\ FLPATP Research Laboratory $N^{\circ} 72$ \\ Faculty of Letters and Languages \\ University of Tlemcen, Tlemcen, Algeria
}

\begin{abstract}
The main interest of this research paper is the exploration of the use of Black English in literature,selecting the American novel: The Adventures of Huckleberry Finn, henceforth (AHF),(1884)by Mark Twain(1853-1910) as a field of investigation. This novel is chosen since it is a fertile scope ofthe study, abundantwith various cultural elements used by characters. The focus is set on a selection of literary, linguistic, and sociolinguistic approaches. The data gathered from the novel have been analyzed and interpreted to provide and reflect a vivid image of the novel's fictional characters with a purpose to increase dialect awareness among readers of literary dialect. The study of the implementation of vernacular elements in American literature does not only extract the enjoyable side about the character's social background but also offers a unique glamour and beauty to American literary works.
\end{abstract}

Keywords: Black English Vernacular,cultural aspects,Huckleberry Finn,literary dialect, Mark Twain,sociolinguistic factors

Cite as: ILES, Y., \& BELMEKKI, A. (2020). The Use of Black English in American Literature: The Case of Mark Twain's Huckleberry Finn. Arab World English Journal for Translation \& Literary Studies 4 (1) 237-.253.

DOI: http://dx.doi.org/10.24093/awejtls/vol4no1.19 